\title{
Norwegian support for tackling health inequalities in Lithuania: the process, pitfalls and results
}

\author{
Mindaugas Stankunas', Ramune Kalediene ${ }^{1}$, Rolanda Valinteliene ${ }^{2}$, Rimantas Stukas ${ }^{3}$, Aurelijus Veryga', \\ Ausra Berzanskyte ${ }^{3}$, Raimonda Janoniene' ${ }^{2}$, Gintare Petronyte ${ }^{2}$, Kastytis Smigelskas', leva Radzeviciute ${ }^{2}$, \\ Neringa Seseikaite', Egle Rimaviciene', Vilma Jasiukaitiene'
}

${ }^{1}$ Lithuanian University of Health Sciences, Kaunas, Lithuania

${ }^{2}$ Institute of Hygiene, Vilnius, Lithuania

${ }^{3}$ Vilnius University, Vilnius, Lithuania

\begin{abstract}
Socioeconomic inequalities in health and health care are important challenges for public health. In terms of health inequalities, Lithuania is among the most unfavourable countries in the European Union. In 2014, the Lithuanian Parliament approved its "Health Programme 2014-2025". One strategic goal of this programme is to reduce health and health care inequalities in Lithuania.

Between 2014 and 2016 the Lithuanian University of Health Sciences, Vilnius University, Klaipeda University and the Institute of Hygiene implemented a project called "Development of a Model for Strengthening Capacities to Identify and Reduce Health Inequalities". This project was financed by the Norwegian Financial Mechanism 2009-2014 Programme "Public Health Initiatives" and implemented in 2014-2016. The purpose of the project was to develop an evidence-based platform for health and health care inequalities to monitor and strengthen the administrative capacities of personnel involved in policy making at national and municipal levels. It included four main actions: 1) analysis of the present situation in monitoring and reducing health inequalities; 2) development of a sustainable health inequalities monitoring system; 3) development of a set of recommendations for public health professionals for health inequalities reduction; and 4) capacity development of public health professionals and health policy makers in the area of health inequalities.

We expect that recommendations coming from this project will contribute to change practices in the target groups, thereby improving public health and reducing health and health care inequalities in Lithuania. Moreover, this model could serve as an example relevant for other countries confronted with the task of tackling health inequalities.
\end{abstract}

KEY WORDS: health inequalities, socioeconomic differences, Norwegian support, Lithuania.

ADDRESS FOR CORRESPONDENCE: Prof. Mindaugas Stankunas, Lithuanian University of Health Sciences,

A Mickeviciaus 9, 44307 Kaunas, Lithuania, e-mail: mindstan@gmail.com

\section{INTRODUCTION}

Socioeconomic inequalities in health and health care are major challenges for public health in most countries. However, the vast majority of scientific data suggest that these inequalities are more expressed in countries in transitions [1]. In terms of health inequalities, Lithuania ranks among the countries with the most unfavourable situation in the European Union. A recent record linkage study suggested significant mortality inequalities exist for all socioeconomic indicators in Lithuania. The most remarkable inequalities were reported by occupation (manual vs. other/non-manual; relative risk for males -3.4 , females -2.8 ) and economic activity status (unemployed vs. inactive/employed; relative risk for males - 2.7, females - 3.1). Risk differences increased from 2005 to 2007, then began to decline [2]. 
Large inequalities are reported by level of education as well. European studies have clearly demonstrated a downward trend in all-cause mortality among both low- and high-educated persons in many European countries, with the exception of Lithuania, where mortality increased among the low-educated [3].

In 2014, the Lithuanian Parliament approved a "Health Strategy for 2014-2025" [4]. One of its strategic goals is to reduce health and health care inequalities in Lithuania. A more specific and detailed agenda is outlined in "Action Plan for Reduction of Health Inequalities in Lithuania 2014-2023", which was approved by the Ministry of Health [5]. This action plan focuses on specific measures, which may contribute to reducing health inequalities in certain regions of the country, as well as differences in access to health care and unequal distribution of health determinants [5]. The presence of these legal and political documents illustrates, that the tackling of health inequalities has become a priority issue on the Lithuanian public health agenda.

\section{MAIN TEXT}

In order to reduce health inequalities, Lithuania has implemented the project "Development of a Model for Strengthening Capacities to Identify and Reduce Health Inequalities". This project was financed by the Norwegian Financial Mechanism 2009-2014 Program "Public Health Initiatives" and implemented in 2014-2017 by the Lithuanian University of Health Sciences, Vilnius University, Klaipeda University and the Institute of Hygiene [6]. The aim of the project was to develop an evidence-based platform for monitoring health and health care inequalities and strengthening the administrative capacities of persons involved in policy making at national and municipal levels. The framework of the project has four main actions: 1) analysis of the present situation in monitoring and reducing health inequalities; 2) development of a sustainable health inequalities monitoring system; 3) development of a set of recommendations for public health professionals for health inequalities reduction; and 4) capacity development for public health professionals and health policy makers in the area of health inequalities.

\section{ANALYSIS OF THE PRESENT SITUATION IN HEALTH INEQUALITIES MONITORING AND REDUCTION}

In the beginning of the project (January - March 2015) the national survey was carried out. It aimed to identify possibilities and pitfalls related to health inequalities monitoring and reduction in Lithuania. This survey totally included 468 respondents, representing different national and municipal level institution, which were involved in monitoring and reducing health inequalities. Including, but not limited to Ministry of Health of Lithuania and subordinated institutions (State Mental Health Centre, Centre for Communicable Dis- eases and AIDS, Centre for health education and Disease prevention, Institute of Hygiene), municipal public health bureaus, administrations of municipalities, other national institutions (Ministry of Education and Science, Ministry of Environment, Ministry of Social Security and Labour, Ministry of Transport and Communications, Department of Physical Education and Sports, Drug, Tobacco and Alcohol Department) and local institutions (community health boards, various non-governmental organizations, schools). This survey combined quantitative and qualitative research methodologies. The main research characteristics and findings are presented in Table 1. Study results have revealed that the most common obstacles and pitfalls for tackling health inequalities are as follows: lack of credibility of statistical data, lack of uniform attitude towards health inequalities, lack of leadership and weak intersectoral collaboration. A more detailed description of this study and results are presented elsewhere [7-14]. These outcomes implicitly supported the directions for further actions in planning and running the project - development of monitoring system, preparations of recommendations for reduction and capacity building for public health professionals.

\section{DEVELOPMENT OF HEALTH INEQUALITIES MONITORING SYSTEM}

Sir Michael Marmot stated: "To address inequalities in health in Europe, our first step must be to address the inequalities in health information. All too commonly where health is poorest, health information tends to be poorest. Health information is absent or incomplete just where we need it most. Health information is crucial in all countries, rich or poor" [15]. This quote much relates to situation in Lithuania before the starting the project.

It was observed that information on heath inequalities related to lifestyle in Lithuania was collected irregularly, using different survey methods, in most cases samples were not representative, therefore were was no possibility to compare lifestyle data, trends over time and between different municipalities. Therefore, one of the project objectives was to improve the situation in monitoring of the health inequalities in Lithuania. The project team has developed standardized questionnaires for collection of information on lifestyle of schoolchildren and adults. In addition, guidelines for monitoring of heath inequality were published and training sessions for public health bureau specialists were organized. It is expected, that guidelines and standardized questionnaires will reduce variations in data collection, ensure reliability of statistical information and make comparable between different administrative regions of Lithuania. Municipal public health bureaus will conduct these surveys in all municipalities of Lithuania (total 60). Meanwhile, the national coordination and supervision of this process is delegated to the Institute of Hygiene. As it was men- 
TABLE 1. The summary of results from project survey

\begin{tabular}{|c|c|c|c|c|}
\hline & I sub-study & II sub-study & III sub-study & IV sub-study \\
\hline $\begin{array}{l}\text { Type of the } \\
\text { study }\end{array}$ & Cross-sectional & Focus-group discussion & Cross-sectional & $\begin{array}{l}\text { Focus-group } \\
\text { discussion }\end{array}$ \\
\hline Sample & $N=236$ & $N=24$ (2 groups) & $N=150$ & $N=58$ (6 groups) \\
\hline $\begin{array}{l}\text { Data } \\
\text { collection } \\
\text { methodology }\end{array}$ & $\begin{array}{l}\text { Questionnaires } \\
\text { were sent by post } \\
\text { to respondents of } \\
\text { selected institutions }\end{array}$ & $\begin{array}{l}\text { Discussions were recorded } \\
\text { and transcribed. Content } \\
\text { analysis was done after mul- } \\
\text { tiple reading }\end{array}$ & $\begin{array}{l}\text { Link to online } \\
\text { questionnaire was } \\
\text { sent to all selected } \\
\text { respondents }\end{array}$ & $\begin{array}{l}\text { Discussions were re- } \\
\text { corded and transcri- } \\
\text { bed. Content analysis } \\
\text { was done after } \\
\text { multiple reading }\end{array}$ \\
\hline Respondents & $\begin{array}{l}\text { Representatives of } \\
\text { Ministry of Health } \\
\text { of Lithuania and } \\
\text { subordinated } \\
\text { institutions (e.g. } \\
\text { State Mental Health } \\
\text { Centre) and other } \\
\text { national institutions } \\
\text { (e.g. Ministry of } \\
\text { Social Security and } \\
\text { Labour) }\end{array}$ & $\begin{array}{l}\text { Representatives of national } \\
\text { level institutions same as in } \\
\text { sub-study I }\end{array}$ & $\begin{array}{l}\text { Municipal public } \\
\text { health bureaus, } \\
\text { administrations } \\
\text { of municipalities }\end{array}$ & $\begin{array}{l}\text { Various municipality } \\
\text { level institutions } \\
\text { involved in tackling } \\
\text { public health }\end{array}$ \\
\hline Main findings & $\begin{array}{l}\text { Still tackling of } \\
\text { health inequalities } \\
\text { is rarely included in } \\
\text { strategic and annual } \\
\text { action plans of diffe- } \\
\text { rent institutions. } \\
\text { Representatives of } \\
\text { health and non-he- } \\
\text { alth sectors agrees } \\
\text { on need to build } \\
\text { greater institu- } \\
\text { tional capacities } \\
\text { in tackling health } \\
\text { inequalities }\end{array}$ & $\begin{array}{l}\text { The main obstacles for mo- } \\
\text { nitoring health inequalities: } \\
\text { credibility of statistical data, } \\
\text { lack of uniform attitude } \\
\text { towards health inequalities, } \\
\text { insufficient detailed analysis, } \\
\text { need of leadership. } \\
\text { The main obstacles of } \\
\text { reducing health inequalities: } \\
\text { absence of sustainability } \\
\text { and explicit priorities, lack of } \\
\text { analytical skills of professio- } \\
\text { nals, and lack of inter-institu- } \\
\text { tional collaboration }\end{array}$ & $\begin{array}{l}\text { Inadequate mo- } \\
\text { nitoring of health } \\
\text { inequalities at } \\
\text { municipal level. } \\
\text { Stressed the need } \\
\text { for multisectoral } \\
\text { collaboration and } \\
\text { setting priorities for } \\
\text { tackling of health } \\
\text { inequalities }\end{array}$ & $\begin{array}{l}\text { Surveillance and } \\
\text { reduction of health } \\
\text { inequalities is not } \\
\text { priority issue at mu- } \\
\text { nicipality level. } \\
\text { Participants em- } \\
\text { phasized lack of } \\
\text { unanimous syste- } \\
\text { matic methodolo- } \\
\text { gy, multisectorial } \\
\text { collaboration, and } \\
\text { information about } \\
\text { evidence -based ef- } \\
\text { fective interventions }\end{array}$ \\
\hline
\end{tabular}

TABLE 2. The structure of lifestyle questionnaires

\begin{tabular}{|l|l|l|}
\hline Survey type & \multicolumn{1}{|c|}{ Lifestyle information } & \multicolumn{1}{|c|}{ General information } \\
\hline Adults' survey & $\begin{array}{l}\text { Physical activity, nutrition habits, alcohol, tobacco, e-ciga- } \\
\text { rettes, illicit drug use, opinion about health, quality of life, } \\
\text { relationships, and environment }\end{array}$ & $\begin{array}{l}\text { Gender, age, weight and height, place } \\
\text { of living, education, marital status, } \\
\text { income }\end{array}$ \\
\hline $\begin{array}{l}\text { Schoolchidren's } \\
\text { survey }\end{array}$ & $\begin{array}{l}\text { Physical activity, nutrition habits, TV and computer, } \\
\text { alcohol, tobacco, e-cigarettes, illicit drug use, violence, } \\
\text { accidents, personal hygiene, prevention programmes in } \\
\text { school }\end{array}$ & $\begin{array}{l}\text { Gender, grade, place of living, family, } \\
\text { language, nationality, pocket-money, } \\
\text { family status }\end{array}$ \\
\hline
\end{tabular}

tioned before, two target groups are identified: adults (18 years and older) and schoolchildren (children from $5^{\text {th }}, 7^{\text {th }}$ and $9^{\text {th }}$ grade). For the rational allocation of the resources schoolchildren and adults' lifestyle surveys are scheduled for different times: schoolchildren survey was carried out in 2016 and will be repeated every four years (in 2020, 2024 etc.); adults' survey will be run in 2018 and repeated every four years (in 2022, 2026 etc.).

The short outlines of questionnaires are presented in Table 2. Lifestyle focus questions were developed based 
on FINBALT Health Monitor study, ESPAD, CINDI Health Monitor, EHIS, HBSC questionnaires. All questionnaires were piloted and modified based on piloting results and recommendations of the experts. Further modifications are not allowed, as to keep them uniform and comparable between municipalities. However, additional question can be added based on specific need of municipalities. Every municipality will calculate the necessary sample size based on its demographic data and guidelines, which were developed during this project. In order to have a unified database, the collected raw data will be entered into "Epidata Entry" data entry form, which will be developed and supervised by Institute of Hygiene. The analysis, publication and dissemination of this information is delegated to the same institute as well. All questionnaires, recommendations, data entry forms, reports are available at http://www.hi.lt/lt/gyvensenos-stebesena.html.

In addition, a new monitoring web-based platform "SveNAS" (http://svenas.lt) was developed. This freely accessible platform allows to compare different mortality based indicators between administrative territories (counties, municipalities, neighbourhoods).

\section{RECOMMENDATIONS FOR REDUCING HEALTH INEQUALITIES}

The third major activity has focused on development of recommendations for reduction of health inequalities. Literature identifies three approaches in tackling health inequalities: 1) to incorporate strategies within the overall public health policy; 2) to tackle the problem through individual health topics such as smoking or nutrition; 3 ) is to have a stand-alone policy addressing inequalities in health [16]. It was decided to develop recommendations based on the second approach. Therefore, the Ministry of Health of Lithuania has identified six key priorities for action in tackling health inequalities in Lithuania: smoking, alcohol abuse, nutrition, physical inactivity, mental health/suicides, and health care accessibility. To effectively address these determinants of health inequalities, detailed recommendations have been developed in the frame of the project. The recommendations are based on scientific evidence and "best-practice" examples [17-19] and include a list of comprehensively described interventions suitable for implementation at national and local (municipality) level (Table 3). Local level interventions were presented and tested in selected (pilot) municipalities of Lithuania. The proposed interventions were found acceptable and ready for putting into practice.

\section{CAPACITY TRAINING IN HEALTH INEQUALITIES MONITORING AND REDUCTION}

The project was concluded in running capacity building seminars for municipal and national level public health specialists, policy makers, specialists from other health related institutions. Total number of participants was 202. These trainings focused on providing knowledge and skills in area of health inequalities, monitoring of health inequalities, practical measures for reduction of health inequalities, and creating and supporting intersectoral networks for tackling this public health problem. Results have shown, that training had a positive impact on the attitudes of the participants regarding monitoring and reducing health inequalities [20]. In addition to this, the textbook on health inequalities was published and distributed among project target groups. The textbook includes such topics as the definition of health inequalities, international "best-practice" in tackling health inequalities, monitoring and evaluation of health inequalities, and measures for reducing health inequalities [21]. It will serve not only as material for capacity building seminars, but will be used both for undergraduate, postgraduate and continuous education, assuring wide dissemination of methodologies for evaluation of health inequalities, contemporary theories explaining the roots of health inequalities, as well as evidence-based practices for addressing this challenge.

\section{CONCLUSIONS}

It is expected that guidelines and recommendations for inequalities monitoring and reduction will be regularly used by the target groups for improving health of population and reducing health and health care inequalities in Lithuania. Moreover, this practice could serve as a transferable example for other countries.

\section{ACKNOWLEDGEMENTS}

This research was funded by implementing the project "Development of a Model for the Strengthening of the Capacities to Identify and Reduce Health Inequalities" (No. NOR-LT11-SAM-01-TF-02-001), which is financed by the Norwegian financial mechanism 20092014 programme No. LT11 "Public Health Initiatives".

The authors would like to acknowledge people who contributed to this project: Tomas Vaiciunas, Reda Moceviciene, Marija Jakubauskiene, Skirmante Sauliune, Laura Nedzinskienė, Jolanta Valentiene, Vincentas Liuima, Snieguole Kaseliene, Gene Surkiene, Mindaugas Butikis, Kestutis Zagminas, Alvydas Navickas, Vilma Kriaucioniene, Iveta Petraityte, Virginija Kanapeckiene, Mindaugas Stelemekas, Vaida Liutkute, Roza Joffe, Lolita Pilipaviciene, Laimonas Siupsinskas, Arnoldas Jurgutis, Neringa Tarvydiene, Vytenis Kalibatas, Faustas Stepukonis, Jurgita Vladickiene, Olga Mesciarinkova-Valiuliene, Eimante Zolubiene, Apolinaras Zaborskis, Ruta Butkeviciene, Kristina Selli and many more. In addition, authors want to thank for Ministry of Health of the Republic of Lithuania and colleagues from Norwegian Public Health Institute (especially Andrej Grjibovski, Marte Kvernland, Heidi Lyshol) for their support in running this project. 
TABLE 3. Recommendation for reducing health inequalities in Lithuania

\begin{tabular}{|c|c|c|}
\hline \multirow{2}{*}{$\begin{array}{l}\text { Area of recom- } \\
\text { mendations }\end{array}$} & \multicolumn{2}{|c|}{ Recommendations } \\
\hline & National level & Local level \\
\hline Smoking & $\begin{array}{l}\text { Excise increase for tobacco } \\
\text { Prohibition of advertisement, promotion, and sup- } \\
\text { port of tobacco products } \\
\text { Assistance to quit smoking } \\
\text { Protection against passive smoking } \\
\text { Decrease of illicit tobacco production } \\
\text { Public awareness about harm of tobacco }\end{array}$ & $\begin{array}{l}\text { Stricter control of commerce } \\
\text { Implementation of screening and short } \\
\text { consulting } \\
\text { Establishment of non-smoking areas }\end{array}$ \\
\hline Alcohol abuse & $\begin{array}{l}\text { Decreased access of alcohol beverages } \\
\text { Regulation of alcohol marketing } \\
\text { Regulation of alcohol pricing } \\
\text { Enhanced control of drunk driving } \\
\text { Improvement of monitoring and surveillance } \\
\text { Decrease of consequences of alcohol abuse and } \\
\text { poisoning }\end{array}$ & $\begin{array}{l}\text { Stricter licensing } \\
\text { Implementation of screening and short } \\
\text { consulting } \\
\text { Implementation of interventions for } \\
\text { school children and their environment } \\
\text { (family and community) }\end{array}$ \\
\hline Nutrition & $\begin{array}{l}\text { Development and support of nutrition monitoring } \\
\text { system } \\
\text { Regulation of prices of food. Additional taxes on high } \\
\text { density food; subsidy on fruit and vegetables } \\
\text { Health information campaigns } \\
\text { Support of increase for supply of healthy food }\end{array}$ & $\begin{array}{l}\text { Literacy of health nutrition } \\
\text { Development of skills for healthy nutrition } \\
\text { Dietary counselling interventions } \\
\text { Better organization of nutrition at schools } \\
\text { Fruit and vegetable promotion }\end{array}$ \\
\hline $\begin{array}{l}\text { Mental } \\
\text { health/suicides }\end{array}$ & $\begin{array}{l}\text { Preparation and implementation of national action } \\
\text { plan in suicide prevention } \\
\text { Improvement of reliable system of suicide monito- } \\
\text { ring and assessment of suicide prevention }\end{array}$ & $\begin{array}{l}\text { Constructing the suicide prevention algo- } \\
\text { rithms at municipality level }\end{array}$ \\
\hline $\begin{array}{l}\text { Health care } \\
\text { accessibility }\end{array}$ & $\begin{array}{l}\text { Development the monitoring system of accessibility } \\
\text { to health care services (at national level) } \\
\text { Develop the sustainable process for ensuring adequ- } \\
\text { ate quality of health services for all groups of society }\end{array}$ & $\begin{array}{l}\text { Development the monitoring system of } \\
\text { accessibility to health care services (at } \\
\text { municipality level) } \\
\text { Strengthen cooperation with partners } \\
\text { from other sectors in organizing and } \\
\text { running different disease prevention } \\
\text { programs } \\
\text { Ensure the equal possibilities for the first } \\
\text { contact with health care providers for all } \\
\text { groups of society }\end{array}$ \\
\hline
\end{tabular}

\section{ACKNOWLEDGEMENTS FROM EDITORS}

Editors would like to acknowledge the invaluable assistance of Prof. Leif Aaro and Mr. Scott Thompson in the preparation of the final version of this article.

\section{DISCLOSURE}

Authors report no conflict of interest.

\section{References}

1. Mackenbach JP, Stirbu I, Roskam AJR, et al. Socioeconimic Inequalities in Health in 22 European Countries. N Engl J Med 2008; 358: 2468-2481.

2. Kalediene R, Prochorskas R, Sauliune S. Socio-economic mortality inequalities in Lithuania during 2001-2009: the record linkage study. Public Health 2015; 129: 1645-1651. 
3. Mackenbach JP, Kulhanova I, Artnik B, et al. Changes in mortality inequalities over two decades: register based study of European countries. BMJ 2016; 353: i1732.

4. Resolution for Lithuanian Health Program Approval 2014-2025. No. 2014-09403. Seimas of the Republic of Lithuania, Vilnus 2014

5. Action plan approval for reducing health inequalities in Lithuania 2014-2023. No. 2014-10332. Ministry of Health, Vilnius 2014.

6. Stankunas M, Kalediene R. Lithuania is tackling health inequalities with support from Norway Grants program. Public Health 2017; 149: 28-30.

7. Petronyte G, Aguonyte V, Valinteliene R, et al. Stakeholders' attitudes towards intersectoral collaboration in the area of health inequalities. Health Policy and Management 2016; 9: 27-41.

8. Kaseliene S, Mesceriakova-Veliuliene O, Vladickiene J, et al Monitoring health inequalities at the municipal level Lithuanian experience. Open Med 2017; 12: 163-170.

9. Vladičkienė J, Jasiukaitienè V, Kaselienè S, et al. Activities of representatives of municipalities and specialists of public health bureaus in monitoring and reducing health inequalities. Visuomenès sveikata 2017; 76: 61-67.

10. Stepukonis F, Butkeviciene R, Berzanskyte A, et al. Administrative capacities to identify and reduce health inequalities in Lithuanian municipalities: qualitative approach. Sveikatos mokslai/ Health Sciences in Eastern Europe 2017; 27: 87-91.

11. Berzanskyte A, Jakubauskiene M, Butkeviciene R, et al. Health policy strategy in local level: experience from the country with high health inequalities. Eur J Public Health 2015; 25 (Suppl 3): ckv176.019.

12. Vladickiene J, Kalediene R, Zaborskis A, et al. Attitudes of public health professionals' towards monitoring health inequalities in Lithuania: Eur J Public Health 2015; 25 (Suppl 3): ckv176.146.

13. Jociute A, Aguonyte V, Valinteliene R, et al. Challenges in tracking health inequalities from the perspective of stakeholders in national level. Eur J Public Health 2015; 25 (Suppl 3): ckv175.062.

14. Petronyte G, Aguonyte V, Valinteliene R, et al. The capacities of the health and non-health sectors in identifying and reducing health inequalities. Eur J Public Health 2015; 25 (Suppl 3): ckv176.150.

15. European Health Information Initiative. Copenhagen; World Health Organization Regional Office for Europe, 2016. Available from: https://eupha.org/repository/advocacy/EHII_Booklet_EN_rev1.pdf (accessed: 17 November 2016).

16. Crombie IK, Irvine L, Elliot L, et al. Closing the Health Inequalities Gap: An International Perspective. World Health Organization, Copenhagen 2005.

17. Hill S, Amos A, Clifford D, et al. Impact of tobacco control interventions on socioeconomic inequalities in smoking: review of the evidence. Tob Control 2014; 23: e89-97.

18. McGill R, Anwar E, Orton L, et al. Are interventions to promote healthy eating equally effective for all? Systematic review of socioeconomic inequalities in impact. BMC Public Health 2015; 15: 457

19. Ball K, Carver A, Downing K, et al. Addressing the social determinants of inequities in physical activity and sedentary behaviours. Health Promot Int 2015; 30: ii8-ii19.
20. Stankunas M, Kalediene R, Kaseliene S, et al. Norway Grants support capacity building for tackling health inequalities in Central and Eastern Europe. Popul Health Manag [online ahead of print]. Available from: https://doi.org/10.1089/ pop.2017.0074 (accessed: 5 July 2017).

21. Kalediene R (ed.). Health inequalities: experience and perspectives. ARX Reklama, Kaunas 2017

\section{AUTHORS' CONTRIBUTIONS}

$M S, R V, R S, A V, A B, G P, R K, R J, K S, N S$, VJ prepared the research concept of the publications. MS, NS collected data. MS analysed data. MS, RK, RJ, KS, ER wrote the article. All authors have revised the paper and finally approved it. 